\title{
SEDIMENTARY BASINS OF RONDÔNIA STATE, BRAZIL: RESPONSE TO THE GEOTECTONIC EVOLUTION OF THE AMAZONIC CRATON
}

\section{AUGUSTO JOSE PEDREIRA ${ }^{1}$ AND RUY BENEDITO CALIARI BAHIA ${ }^{2}$}

\begin{abstract}
The Precambrian framework of South America comprises the Amazonic and the São Francisco cratons, Neoproterozoic mobile belts surrounding them, other Proterozoic mobile belts and cratonic fragments, scattered throughout Brazil. The Phanerozoic record is represented by Paleozoic-Mesozoic intracratonic basins and the Andean Belt. In the southwestern sector of the Amazonic Craton, the (meta) sedimentary basins of Rondônia State record the geotectonic evolution of that craton: 1) Rondônia Basin, an interior sag basin of Neoproterozoic age, has sandstones and conglomerates deposited by braided rivers in response to continental extension during Rodinia breakup; 2) Parecis Basin, of Paleozoic-Mesozoic age, is a rift-sag basin. The rifts represent reactivation of older structures and are filled by Silurian alluvial fans and Carboniferous glacial sediments. The abortion of the rifts led to subsidence and the sediments of the interior sag basin also record the geotectonic and climatic events of West Gondwana, such as the Permian, Jurassic and Cretaceous deserts, the opening of the Atlantic Ocean and unconformities related to global tectonic events. The Cenozoic Guapore Basin, largely unknown, records neotectonic events related to rotation and translation of the South American plate.
\end{abstract}

Keywords: Amazonic Craton, sedimentary basins, geotectonics, Rondônia State, Brazil

INTRODUCTION The geotectonic framework of South America (Fig. 1) comprises: two major cratonic areas (Amazonic and São Francisco cratons), surrounded by Neoproterozoic fold belts; Paleo to Mesoproterozoic domains with fold belts separating cratonic fragments; intracratonic basins whose ages range from the Paleozoic to the Recent; and the Andean Belt, which encompasses Meso to Neoproterozoic domains, recorded both in grouped and scattered outcrops, and in sub-surface (Brito Neves et al. 1996). The Amazonic Craton is the product of several collages that accreted mobile belts to a central nucleus, older than 2.3Ga (Tassinari and Macambira 1999). In figure 2, the central nucleus and the mobile belts are shown, with their respective ages, according to Valente (1999).

In Rondônia State, the Rio Negro-Juruena Mobile Belt was divided by Scandolara et al. (1999) into three tectono-stratigraphic terranes (Roosevelt, Jamari and Nova Brasilândia), with formation ages ranging from $2.2 \mathrm{Ga}$ to $1 . \mathrm{VGa}$, according to $\mathrm{U} / \mathrm{Pb}$ and $\mathrm{Sm} / \mathrm{Nd}$ data. In this study, the sedimentary basins of Rondônia State (Fig. 3) are analyzed regarding the relationships between their sedimentary features and the geotectonic evolution of the Amazonic Craton.

RONDÔNIA BASIN The sediments of Palmeiral Formation, deposited by braided rivers in Rondônia Basin (Bahia 1997), are preserved in grabens (Fig. 3). They consist essentially of sandstones and clast supported conglomerates. The sandstones are fine to medium grained, although coarse fractions may occur occasionally. In general the selection is moderate to good; however, they are poorly selected when intercalated as lenses in the conglomerates. The composition of the sandstone comprises quartz, chert, phyllosilicates such as kaolinite and illite and scattered grains of feldspar and volcanic rocks. The Palmeiral Formation sandstones are classified as kaolinitic-illitic quartzarenite (Folk 1974). The conglomerate clasts consist of quartz-arenite, quartz, chert, quartzite and acid volcanic rocks. The clasts are well rounded and imbrication is common, indicating the direction of paleocurrents.

The paleocurrents of the formation, measured in places widely apart, indicate sediment transport from NNE to SSW and from north to south (Fig. 4). These paleocurrent directions are in agreement with measurements taken farther south in the Arco Iris and Fortuna Formations in Santa Barbara range (Mato Grosso State, Brazil) and Huanchaca Group (Huanchaca range, Bolivia), and Cuatro Carpas Formation (also in Huanchaca range).

Sandstone petrographic evidence indicates a quartz-feldspathic petrofacies for these rocks. Such petrofacies is characteristic of a source area that was uplifted basement in cratonic interiors (Dickinson 1985). Additionally, the clast composition of the conglomerates suggests volcanism in the source. However, as in their composition predominate ultra to moderately durable rocks (Abbott and Peterson 1978), it has not been possible to estimate the transport distance.

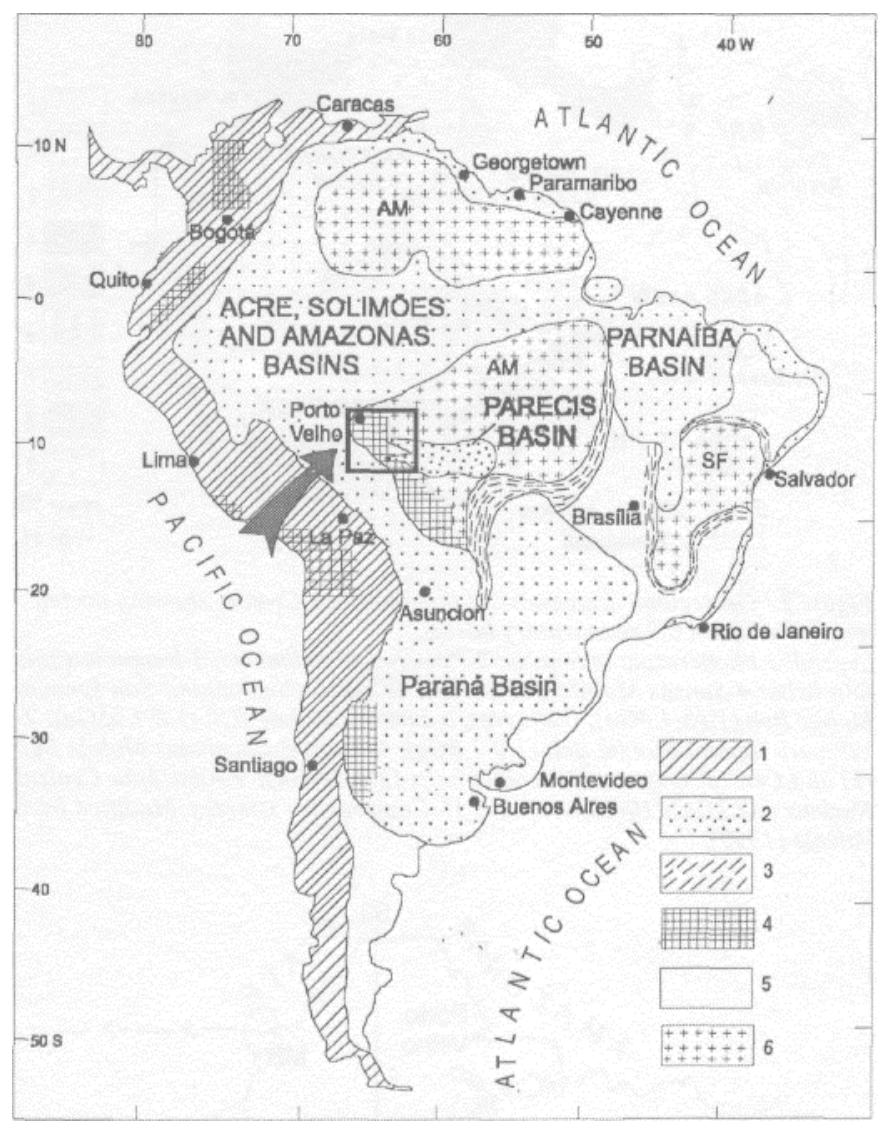

Figure 1 - Geologic-geotectonic sketch of South America, showing the region of the present study. Legend: 1- Andean Chain; 2-Major Phanerozoic basins; 3-Neoproterozoic marginal belts; 4-Meso to Neoproteroz.oic domains; 5-Other belts and cratonic fragments; 6-Cratons: AM-Amazonic; SF-São Francisco. Modified from Brito Neves et al. (1996).

PARECIS BASIN The Parecis Basin in the State of Rondônia (Fig. 3) is a rift-sag type basin. The rifts opened on weakness zones of the basement during an extensional event in the Amazonic craton, following Rodinia break-up ( 1.0-0.75Ga). Within them were deposited the Cacoal and Pimenta Bueno Formations (table I and Figs. 5A and 5B). Bahia and Pedreira (1996), and Pedreira (1998) recently analyzed their depositional environments. 
By Late Carboniferous to Permian, the lithospheric extension ceased; the rift area flexurally subsided to form a sag basin, whose limit is about $100 \mathrm{~km}$ northwest of the town of Vilhena. In Rondônia State, this basin received the sediments of the Fazenda da Casa Branca, Botucatu and Parecis Formations (table II and Fig. 5C). Between Botucatu and Parecis Formations, are the basaltic flows of the Anari Formation (table II).

GUAPORE BASIN This basin (Fig. 3) comprises immature Tertiary laterite, Quaternary alluvium and swampy deposits, the latter related to seasonal floods. The unconsolidated sediments of this basin are gravels, sands and clays. The presence of consolidated sediments under this cover is highly speculative, but not impossible, taking into account the presence of the Acre Basin (Feijó and Souza 1994), about $200 \mathrm{~km}$ northwest of Guajará Mirim (Fig. 3). Satellite imagery of the

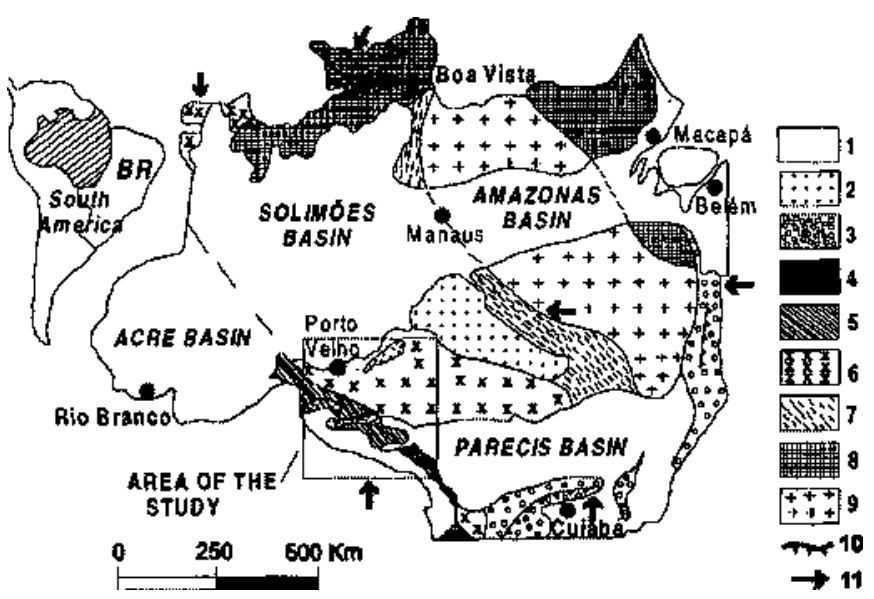

Figure 2 - Geotectonic framework of the Amazonic Craton, showing accreted mobile belts and the sedimentary basins.

Legend: 1 Phanerozoic sediments; 2-Proterozoic sediments; 3-Neopwterozoic fold belts; 4-Sunsás Mobile Belt (1.25-l.OGa); 5-Rondôniano-San Ignacio Mobile Belt (1.45-1.3Ga): 6-Rio Negro-Juruena Mobile Belt (1.8-J.55Ga): 7Ventuari-Tapajos Mobile Belt (1.9-J.8Ga); 8-Maroni-ltacaiunas Mobile Belt (1) and Central Guyana (2) mobile belts (2.2-1.9Ga); 9-Amazônia Central Nucleus (>2.3Ga); 10-Thrust fault; 11-Compressive stresses. Modified from Valente (1999).

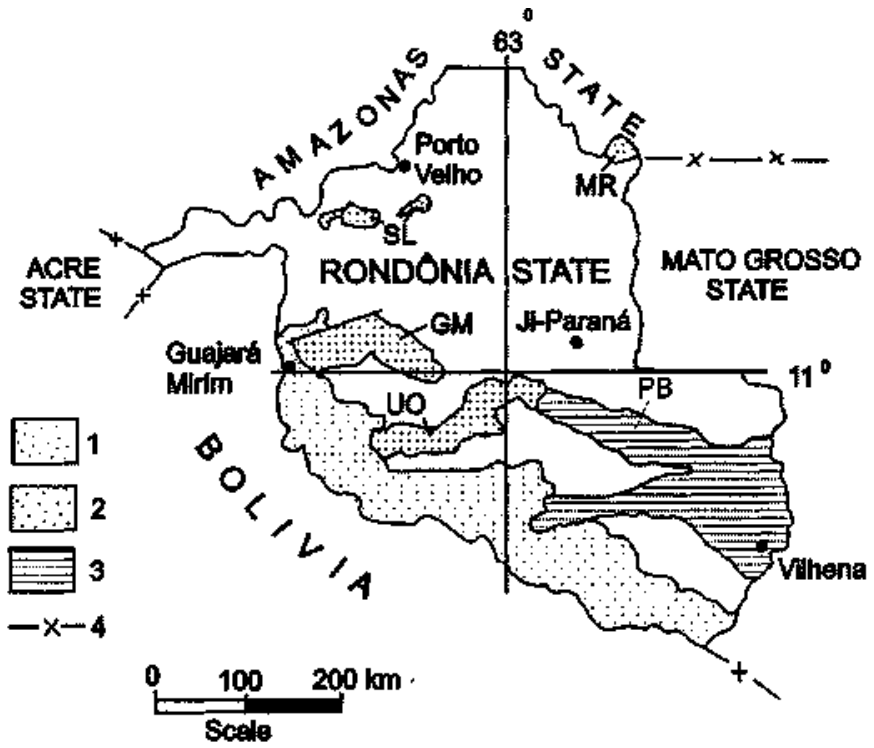

Figure 3- Sedimentary basins of Rondônia State. I-Guaporé Basin (Cenozoic); 2-Parecis Basin and Pirnenta Bueno (PB) Graben (Paleozoic to Mesozoic); 3-Rondônia Basin (Neoprotewzoic) whose sediments are preserved in São Lourenço (SL), Guajará Mirim (GM) and Uopianes (UO) grabens. and in Madeirinha river (MR) region; 4-State boundary. region shows several drainage anomalies, such as river control by fractures, sharp turns and damming of rivers, suggesting neotectonic deformations.

DISCUSSION AND CONCLUSIONS The sedimentary basins of Rondônia State are located in the interior of the South American continent, away from the Andean margin (Fig. 1); the Parecis Basin is saucer shaped and is installed on failed rifts (Fig. 5C). Such features characterize the basins as intracratonic (Klein 1995). According to this author, the evolution of intracratonic basins comprises 1) continental extension, 2) thermal subsidence on a wide area, and 3) later isostatic readjustments.

Continental extension and thermal subsidence on a wide area are recorded by the Palmeiral Formation (Rondônia Basin), whose sediments are presently preserved in grabens opened during the

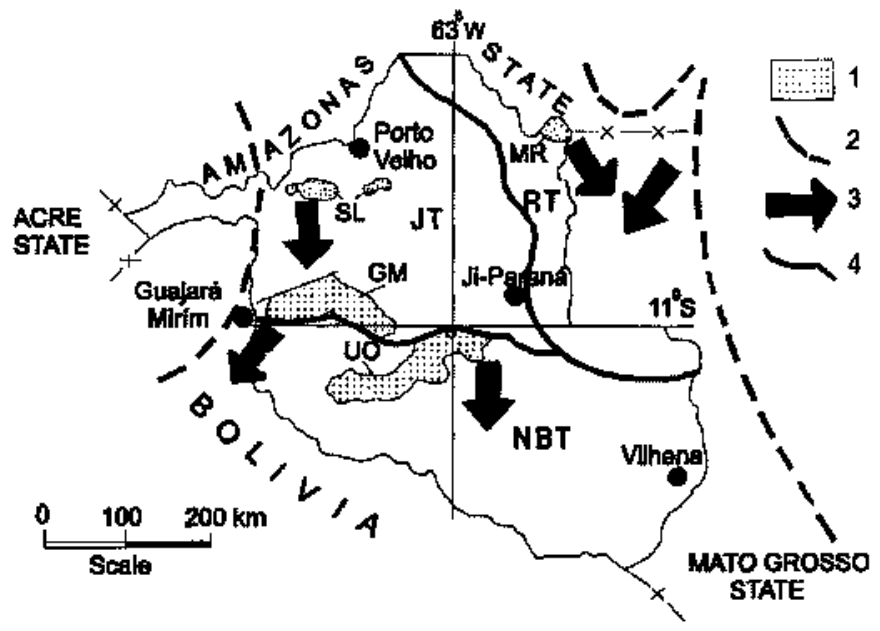

Figure 4-Main outcrops of the Palmeiral Formation on the tectonostratigraphic terranes of Rondonia, showing, approximately, its previous extension, and the paleocurrent directions. Legend: I-Palmeiral Formation; 2-Possible outer limit of previous outcrops; 3-Direction of paleocur rents; 4Limit of terrane; SL-São Lourenço Graben; GM-Guajará Mirim Graben; UOUopianes Graben; MR-Madeirinha river region; JT-Jamari Terrane; NBTNova Brasilândia Terrane; RT-Roosevelt Terrane.
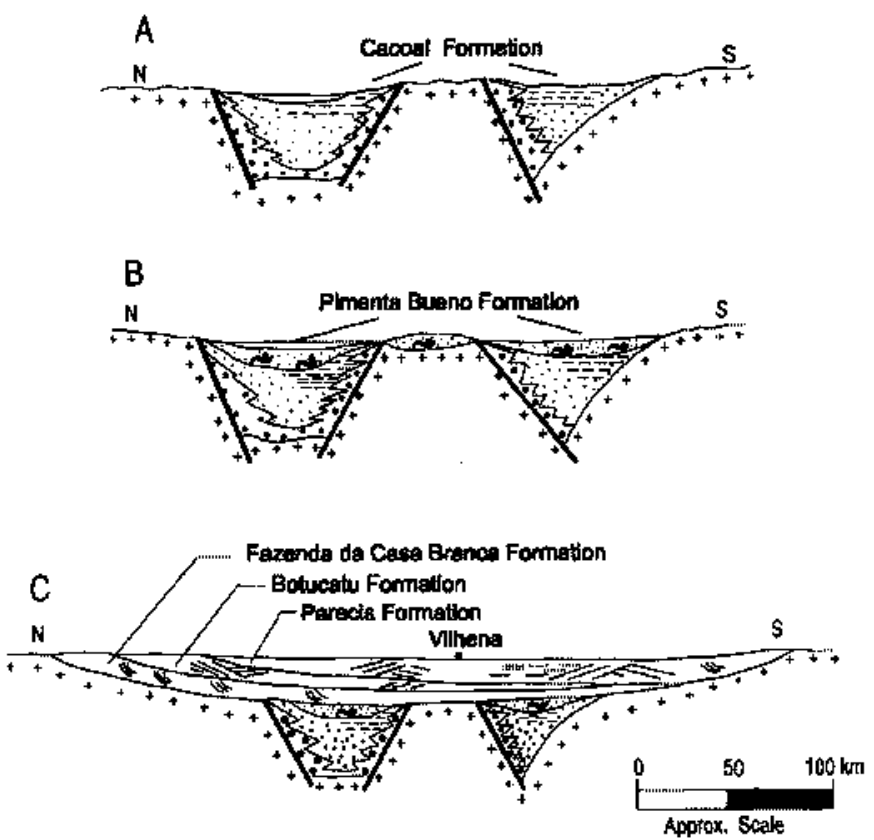

Figure 5 - Schematic geologic section showing the evolution of the Parecis Basin (the basalts of Anari Formation are not shown). A-Rifting; BGlaciation; C-Abortion of the rifts and subsidence. 
Table I - Sedimentary rocks of Parcels Basin rift phase, Rondônia State.

\begin{tabular}{|l|c|c|l|l|}
\hline \multicolumn{1}{|c|}{ AGE } & $\begin{array}{c}\text { THICK- } \\
\text { NESS }\end{array}$ & FORMATION & DESCRIPTION & INTERPRETATION \\
\hline Carboniferous & $76 \mathrm{~lm}$ & Pimenta Bueno & $\begin{array}{l}\text { Horizontal, and trough and tabular cross bedded sandstones with shale intercalation; } \\
\text { pelites with dropstones; matrix supported polymictic conglomerates; shales with coal } \\
\text { lenses and brown shales with siltstone intercalations }\end{array}$ \\
\hline Silurian & $230 \mathrm{~m}$ & Cacoal & $\begin{array}{l}\text { Dolomites with desiccation structures; alternance of brown and greenish shales with } \\
\text { massive, and trough cross-bedded sandstones; matrix supported conglomerates with } \\
\text { angular boulders. }\end{array}$ & $\begin{array}{l}\text { Lacustine, } \\
\text { and alluvial fans }\end{array}$ \\
\hline
\end{tabular}

Table II - Sedimentary and igneous rocks of Parecis Basin sag phase in Rondônia State.

\begin{tabular}{|l|c|c|l|l|}
\hline \multicolumn{1}{|c|}{ AGE } & $\begin{array}{c}\text { THICK- } \\
\text { NESS }\end{array}$ & FORMATION & DESCRIPTION & INTERPRETATION \\
\hline Cretaceous & $90 \mathrm{~m}$ & Parecis & $\begin{array}{l}\text { Intertedded shales and cross-bedded sandstones; bimodal sandstones with large } \\
\text { scale tabular cross bedding; tabular and trough cross-bedded sandstones with } \\
\text { pebble floored channels. }\end{array}$ & $\begin{array}{l}\text { Desertic with dunes } \\
\text { and interdune lakes, } \\
\text { fluvial braided }\end{array}$ \\
\hline $\begin{array}{l}\text { Jurassic/Early } \\
\text { Cretaceous }\end{array}$ & $?$ & Anari & Aphanitic basalts associated to medium grained diabase dikes. \\
\hline Jurassic & $90 \mathrm{~m}$ & Botucatu & Large scale cross-bedded bimodal sandstones. \\
\hline $\begin{array}{l}\text { Permo- } \\
\text { Carboniferous }\end{array}$ & $150 \mathrm{~m}$ & $\begin{array}{l}\text { Fazenda da } \\
\text { Casa Branca }\end{array}$ & $\begin{array}{l}\text { Tabular cross-bedded arkosian sandstone; alternance of siltic shale and matrix } \\
\text { supported conglomerate; clast supported conglomerates with intercalation of } \\
\text { massive arkosian sandstones. }\end{array}$ & $\begin{array}{l}\text { Aeolian, glacial and } \\
\text { fluvial braided }\end{array}$ \\
\hline
\end{tabular}

Rondoniense event (IGa). These phenomena are a response to the breakup of Rodinia supercontinent, when different lithospheric terranes were generated and different kinds of basins were formed among them (Brito Neves et al. 1999). In terms of terrane analysis (Howell 1995), the Palmeiral Formation provides provenance link to the central part of the Amazonic Craton (compare Figs. 2 and 4), and represents an overlap sequence, since it covered the Jamari, Roosevelt and Nova Brasilândia terranes of Rondônia, of different ages (Scandolara et al 1999; Fig. 4). It is presently preserved in grabens on the Jamari Terrane (São Lourenço and Guajará Mirim grabens) and the Nova Brasilândia Terrane (Uopianes Graben), and as cover on the Nova Brasilândia terrane (Madeirinha river region). Saes (1999) found similar relationships for the correlative Aguapei, Huanchaca, Sunsas, Novos Dourados groups and Amolar Unit, that crop out southwest of Mato Grosso State (Brazil), and east Bolivia.

The Parecis Basin began as a rift system of NW-SE direction (Braga and Siqueira 1996). The stresses that lead to rifting are supposed to be related to reactivation of older structures (see, in Fig. 3 , the continuity of the Uopianes and Pimenta Bueno grabens), due to extension in the upper plate owing to the Andean subduction. Within the rifts were deposited the alluvial fans, deltaic and lacustrine sediments of the Cacoal Formation (table I). The Pimenta Bueno Formation was deposited (Fig. 5B) during a continent-wide Carboniferous glaciation in southern Gondwana (Scotese 1997a), indicated by the diamictite-dropstone association of the formation (Bahia and Pedreira 1996).

The abortion of the rifts led to subsidence over a wide area, and to the deposition of the Parecis sag-type basin. This subsidence may be attributed to compressive stresses in the Andean region, in analogy to the subsidence in Illinois Basin (USA), caused by collisions along the eastern and southern margins of North America (Klein 1995). In Rondônia State only the Fazenda da Casa Branca, Botucatu, Anari and Parecis Formations crop out (table II and Fig. 5C). The above mentioned Late Carboniferous glaciation lasted until at least Early
Permian; and by Late Permian, vast deserts covered East Gondwana (Scotese 1997b). Caputo (1984) suggested the deposition of the Fazenda da Casa Branca Formation fluvial and aeolian sediments in a periglacial environment. The large-scale cross-bedded sandstones of the Botucatu Formation are suggestive of aeolian dunes.

The calc-alkaline basaltic flows of the Anari Formation are related to the opening of the South Atlantic Ocean by 140 m.y. ago (Cretaceous), separating South America from Africa. In the Cretaceous, under a climate warmer than the present (Scotese 1997c), were deposited the sediments of the Parecis Formation. Pedreira (1998) determined its aeolian facies as represented by large-scale cross bedded sandstones, intercalated with fluvial channels. The channels scoured into this formation indicate little frequent avulsion, being an evidence of slow subsidence rate during its deposition. However, there is evidence in the basin of sedimentary sequences separated by regional unconformities related to tectonic events (Siqueira and Teixeira 1993).

The subsidence episodes of the Parecis Basin may be correlated to other Brazilian intracratonic basins, such as Parana Basin (Fig. 1): in the latter, major subsidence episodes were in the Silurian/Devonian and Permo-Carboniferous (Klein 1995), respectively coincident with the rift and sag phases of the Parecis Basin.

The Guapore Basin, except for its cover, is largely unknown. The deformation phases detected in it are related to a neotectonic framework established from the Upper Pleistocene until the present times. It resulted from the intraplate deformation imposed by E-W compression, responsible by the generation or reactivation of NW-SE and N-S transpressive and NE-SW transtensive lineaments (Souza Filho et al. 1999), related to the rotation and translation of the South American plate. 


\section{References}

Abbott P.L. \& Peterson G.L. 1978. Effects of abrasion on conglomerate clast populations: Examples from Cretaceous and Eocene conglomerates of San Diego area, California. Journal of Sedimentary Petrology, 48: 31-42.

Bahia R.B.C. 1997. A Formacao Palmeiral (Proterozoico Superior) na Serra dos Pacaás Novos, $W$ de Rondônia. Belem, Universidade Federal do Pará. (MSc Dissertation).

Bahia R.B.C.and Pedreira A J. 1996. Depósitos Glaciogenicos da Formação Pimenta Bueno (Carbonifero) na Região de Rolim de Moura, Sudeste de Rondônia. A Terra em Revista, II (1): 24-29.

Braga L.F.and Siqueira L.P. 1996. Three Dimensional Modelling of the Basement Topography Beneath Parecis Basin, Brazil, Constrained by Spectral Estimates of Depth to Magnetic Sources. In: Latin American Petroleum Congress, 5. Rio de Janeiro, CONEXPO-ARPEL, October, 1996, 8p

Brito Neves B.B., Winge M., Carneiro M.A .1996. Orogêneses precedendo e tafrogêneses sucedendo Rodinia na América do Sul. São Paulo, Institute de Geociências, Universidade de São Paulo, p. 1-40, (Boletim IG-USP, Serie Cientifica, no. 27).

Brito Neves B.B, Campos Neto M.C., Fuck R.A . 1999. From Rodinia to Western Gondwana: an approach to the Brasiliano-Pan African cycle and orogenic collage. [Abstract] Episodes, 22(3). Retrieved March 11, 2000 from the World Wide Web: http://www.iugs.org/iugs/pubs/epi22-3.htm

Caputo M. 1984. Stratigraphy, tectonics, paleoclimatology and paleogeography of Northern Basins of Brazil. Santa Barbara, University of California (PhD Thesis).

Dickinson W.R. 1985. Interpreting provenance relations from detrital modes of sandstones In: Zuffa G.G. (ed.) Provenance of Arenites. Dordrecht, D. Reidel, 333-361.

Feijo F.J.and Souza R.G. 1994. Bacia do Acre. Boletim de Geociências da Petrobrás, 8:9-16

Folk R.L. 1974. Petrology of Sedimentary Rocks. Austin, Hemphill, $159 \mathrm{p}$

Howell D.G. 1995. Principles of Terrane Analysis; New Applications to Global Tectonics. 2ed. London, Chapman \& Hall, 245p. (Topics in the Earth Sciences, 8)

Klein G.D. 1995. Intracratonic Basins. In: Busby C.J. \& Ingersoll R.V. (eds.) Tectonics of Sedimentary Basins. Cambridge, Blackwell Science, 459-478.

Pedreira A J. 1998. Sistemas Deposicionais e Estratigrafia da Bacia dos Parecis no Estado de Rondônia. Salvador, CPRM, 32 p. (Internal Report).
Saes G.S. 1999. Evolução Tectônica e Paleogeográfica do Aulacógeno Aguapei (1.2l. Ga) e dos Terrenos do seu Embasamento no. Porçáo Sul do Cráton Amazônico. São Paulo, Universidade de São Paulo, 135p. (PhD Thesis).

Scandolara J.E., Amorim J.L., Rizzotto G.J., Quadros M.L., Bahia R.B. 1999. Compartimentação Tectono- Estratigráfica Pré-Cambriana de Rondônia: Subsídios para os Modelos Evolutivos. In: SBG, Simpósio de Geologia da Amazônia, 6, Manaus. Resumos Expandidos, 270-273.

Scotese C.R. 1997a. Late Carboniferous [Web Page]. Retrieved November 6,1999 from the World Wide Web: http://www.scotese.com/late.htm

Scotese C.R. 1997b. Late Permian [Web Page]. Retrieved November 6, 1999 from the World Wide Web: http://www.scotese.com/newpage5.htm

Scotese C.R. 1997c. Late Cretaceous [Web Page]. Retrieved November 6,1999 from the C.R. 1997c. Late Cretaceous [Web Page]. Retrieved No
World Wide Web: http://www.scotese.com/cretaceo.htm

Siqueira L.P.and Teixeira L.B. 1993. Bacia dos Parecis: Nova Fronteira Exploratória da Petrobras. In: Congresso Internacional da Sociedade Brasileira Geofísica, 3, Rio de Janeiro. Resumos Expandidos, 168-173.

Souza Filho P.W.M., Quadros M.L.E.S., Scandolara I.E., Silva Filho E.P., Reis M.R. 1999. Compartimentação morfoestrutural e evidências de atividade neotectonica no sistema fluvial Guaporé-Mamoré-Alto Madeira, Rondônia. In: SBG, Simpósio de Geologia da Amazônia, 6, Manaus. Boletim de Resumos Expandidos, 330-333.

Tassinari C.C.G.and Macambira M.J.B. 1999. Geochronological provinces of the Amazonian Craton. [Abstract] Episodes, 22 (3). Retrieved March 11, 2000 from the World Wide Web: http://www.iugs.org/iugs/pubs/epi22-3.htm

Valente C.R. 1999. Caracteristicas dos Cinturões Móveis do Cráton Amazônico. Goiânia, CPRM, 18p. (Internal Report)

Contribution IGC-197 Received March 13, 2000
Accepted for publication April 29, 2000 